\title{
Ethnolinguistic Nationalism and Other Political Contexts of Maironis
}

\author{
MANFREDAS ŽVIRGŽDAS
}

\begin{abstract}
Widely acclaimed as the Lithuanian national poet, the Catholic clergyman Jonas Mačiulis-Maironis (1862-1932) in his canonical poems of the epoch of national revival expressed his romantic primordialist point of view that every nation has an inherent right to its independence that had been given by divine institution. Linguistic factors determined national identity in Eastern Europe of the late $19^{\text {th }}$ century. Maironis as a follower of linguocentric nationalism modelled the conditions for the elite Lithuanian culture which would be significant at the European level. The longing for the so-called European virtues (universally based on Christian ethics) penetrated through all the poet's world-view, therefore he was impressed by the diligence and activism of Western nations but did not support the ideas of social activism and individual liberties, opposed the ideas of secular philosophical trends, especially socialism and scientism. Eurocentrist motives in his rhetoric did not mean any challenge to the governing conservative Russian regime because they did not invoke opposition to the ideology of Pan-Slavism which was supported by the Tsarist ideologues. The poetical archetype of springtime awakening was related to the youthful activism of the "new" political nations of Eastern and Central Europe. Maironis was one of the first Lithuanian authors who openly criticized ideas of socialism and positivism; on the other hand, he provoked discussions of the enlightened group of the developing Lithuanian-speaking elite. He regarded the slogans of liberty, equality and fraternity as deceptive justification of populism and collective violence. Sceptically regarding parliamentary democracy, he emphasized the principles of Classical-Christian law and justice and the need for solidarity, consciousness and creativity. Maironis related the ideological dispute of conservative and radical trends to the decisive struggle of Christianity and atheism. He was a consistent and orthodox Catholic thinker, the opponent of any revolutionary upheavals; discussing social questions he emphasized that politicians should take into account doctrine of the Holy See on the obligations of Christians and principles of charity.
\end{abstract}

Keywords: national movement; nationalism; Eurocentrism; clericalism; Socialism; scientism 


\section{Poet and Clergyman in the Era of National Awakening}

The aim of this article is to describe the authoritative and inspirational position of Maironis in the process of national self-identification and modern-style nation-building, especially his attitude towards ethnolinguistic nationalism when collective aspirations were deeply linked to the arguments of native language and ethnographic heritage. This position was unambiguous, related to the right-wing, conservative and moralist values and it was a critical target for left-wing secular intellectuals and admirers of socialism. Even Maironis's poetic works could be interpreted as political in the extensive Aristotelian sense of politeia, oriented to the modelling of a socially conscious and patriotic citizen, canonization of national cultural saints and consolidation of national identity.

A notable professor of Catholic theology and Romantic poet Jonas MačiulisMaironis (1862-1932) was the author of only one collection of verses, and his Pavasario balsai (Voices of Spring) was published in four editions during his lifetime in 1895-1920, and each edition was supplemented with newly written and thoroughly revised poems. The political symbolism of spring, awakening and resurrection was important to all dominated and colonialized nations and related to the revolutionary movement called "Spring of Nations" which took place in Central and Southern Europe in the middle of $19^{\text {th }}$ century. In this context, Lithuanian nationalism passed through the initial stage of the creation of nationhood very late because the elite community of ethnic Lithuanians in the last decade of the $19^{\text {th }}$ century was still engaged in literary, historical, philological studies of collective self-identification.

Maironis was not only the author of rebellious patriotic poems: while holding the position of inspector of the Catholic spiritual academy in St. Petersburg until 1909, he was a considerably wealthy and influential person, and his newly-acquired palace in the centre of Kaunas was praised as the meeting place for patriotic Lithuanian-speaking intellectuals, as numerous Catholic charity organizations had been established in it. Maironis's ambitions concerning a bishopric never came true but he had many other clerical titles of honour: from 1912 he was a prelate. The inspired, idealistic and romantic poet Maironis, known from his clandestine lyrics and patriotic anthems, differed considerably from the diplomatic clergyman Mačiulis, or Maculevič, as he was widely known. When Maironis achieved his high social position he decided to return from the capital city of the Russian Empire to the Kaunas spiritual seminary in 1909. He became the rector of this institution and he held this office until the end of his life despite all the intrigues and the clashes of Lithuanian and Polish nationalist movements. He reformed the seminary, introducing the lectures 
on Lithuanian language and sociology. Maironis even had the ambitions of a politician. In 1907 he signed "The Programme Project of the Lithuanian Christian Democratic Union"; he analysed the social contrasts of the industrial era as a conservative Christian moralist. He criticized the acts of violation of human rights, however he used only theological arguments, appealing to the divine authority.

Maironis's personal interests were developing in the atmosphere of the defeat after the unsuccessful Polish-Lithuanian revolt of 1863. In Western Europe after the Franco-Prussian war of 1871 the mood of peace and relative tranquillity, the belle époque, prevailed; urban industry, the proletariat and the politically engaged middle class were strengthening; a new wave of individualism and the movement of civic rights was arising; the leaders of nation states sought to mobilize masses applying nationalist propaganda; and the rationalist intelligentsia challenged the authorities of the "ancient regime". (Bairašauskaite et al. 2011: 16-17)

Nowadays researchers emphasize that the history of the $19^{\text {th }}$ century was a period of radical renovation and modernity which was inspired by the turningpoint of the Great French Revolution of 1789. During this revolution "the new political order was created which was motivated by the idea of national sovereignty" ${ }^{1}$ (Bairašauskaite et al. 2011: 23). The second part of the $19^{\text {th }}$ century was acknowledged as an epoch of prevailing nationalist ideology and separatism, especially among nations that were compelled to struggle for their right to autonomy. The so-called "Spring of Nations" which was traditionally identified with the revolution of 1848 , shocked the Habsburg and Ottoman empires and ensured important concessions to several small nations; some distant responses from the revolutionary past and individual biographical examples has an impact on the national movements in Poland, Ukraine and the Baltic countries even after five decades. According to the social researcher Ernest Gellner, nationalism was related to the feelings of injustice and a need to overcome it, to make sure that the ethnic borders of the community coincide with its political territory:

In brief, nationalism is a theory of political legitimacy, which requires that ethnic boundaries should cut across political ones, and, in particular, that ethnic boundaries within a given state - a contingency already formally excluded by the principle in its general formulation - should not separate the power-holders from the rest. (2008: 1)

1 All the quoted excerpts from Lithuanian works were translated by the author of this article. $-M$. $\check{Z}$. 
A wish for territorial integrity and a political elite of their own ethnic origin maintained the ambitions of the nations that had neither their own state nor rulers.

Maironis supported the Romantic and primordialist point of view that sovereignty of a nation was a natural right. The primordialist idea of a nation as a creature of the highest, divine instance of history was important for the selfidentification of Lithuanian right-wing politicians (Laurinavičius 2013: 27). Later the constructivist view dominated, and nations were regarded as cultural constructs, which were impacted by processes of political self-determination. Maironis was not an enthusiastic follower of the democratic system. However, he approved of the tendency of ethnolinguistic nationalism and was known as a moderate nationalist from his early publications in Auszra newspaper which was printed in Lithuanian Latin letters in East Prussia during the period of 1883-1886 and was banned in tsarist Russia.

In Eastern Europe the linguistic factor determined the identity of a nation. In the late $19^{\text {th }}$ century the fact of printing of books and newspapers in a forbidden alphabet provoked political consequences in Russian-ruled Lithuania. Maironis was regarded as one of the first professional Lithuanian men of letters (he briefly studied literary and historical subjects in Kiev St. Vladimir's university in 1883-4), and later highly influenced literary culture in the Lithuanian language. Maironis as a follower of linguocentric nationalism never doubted that the higher prestige of the native language could support the guarantees of cultural autonomy or national statehood. According to him, Lithuanians needed an example and analogy of cultural struggle. Such analogies were seen in the Slavic nations of Central Europe which were dominated by the dynasty of Habsburgs for centuries:

Ar tai senei, kaip Bulgarai, Serbai, Czekai ir daugumas smulkesniuju Slaviu miegojo be žado. Palenkę sprandą po sunkiu jungu, nupůlę ant dvasēs, rodēsi tiktai geru kąsniu dēl stipresniu aplinkiniu.

[For a long time Bulgarians, Serbs, Czechs and most of the smaller Slavs were sleeping silently. With their necks bent by the burden, mentally degraded, they seemed only a good catch for their stronger neighbours] (S. Z. [Maironis] 1887a: 3).

Maironis declared the immediate demand for the unity of the nation but warned that unity is possible among those who are good (unitas non nisi inter bonos). He encouraged the leaders of the national movement to project their visions onto the stable Christian-oriented intellectual base. 
ŽVIRGŽDAS

The great powers, according to him, live in the state of cultural abundance. However, the small nations have no time for idleness: "Dēl musu reikia labai daugel, nēs mes tepradedame tiktai gyventi kaipo tauta" ["We need many things because we only now begin to exist as a nation"] (S. Z. [Maironis] 1887b: 204). He emphasized especially the demand for books in the vernacular and described the curious situation when the neighbours of Lithuanians - the Latvians and the Finns, who never could boast of heir triumphant history and expansionist traditions - at the end of the $19^{\text {th }}$ century could take inspiration from their epic literary tradition, academic research of folklore and linguistics and drama.

\section{Pan-Slavism and Eurocentrism}

Not all forms of national movement were highly appreciated by Maironis. He was a devoted Catholic priest who followed the Pope's authority uncompromisingly and compared Italian Risorgimento, Garibaldi's struggle for liberation, with the historical invasion of antique Rome by barbarian Huns (in the poem "Roma" ["Rome"] (Maironis 1987: 195-8)); he was said to "overlook" the Polish national revival, their struggle for autonomy from Russia which determined the division of Lithuanian-born noble society and instigated conflicts in the nationally mixed parishes. On the other hand, it was not difficult to glorify the national revival of nations which was supported by the emperors of the Romanov dynasty, self-acclaimed the greatest defender of the Slavs. In the widely distrbuted Russian newspapers of the period educated representatives, leading historians, lawyers and philologists of Czech, Bulgarian, and Serb origin were introduced. However, the official ideology of Pan-Slavism, which was promoted after Russia's defeat in the Crimean War of 1856, was openly related to the Russian imperialism and hostility to Catholicism which in turn was the basis of the cultural identity of the Habsburg dynasty (Avižonis 1957: 30). The loyal Russian journalists did not anticipate that biographies of politically conscious Central European intellectuals could inspire analogies for the struggle of oppressed nations.

The longing for the so-called European virtues penetrated the poet's worldview. The West was not only a geographical dominant, it was related to the characteristics of diligence and activism, as well as to the principles of law and order, and Roman Catholicism was regarded as the foundation of Western traditions. European orientation is vividly marked in the poem Tarp skausmu i garbę (Through Pains to Glory, 1895): "Pažvelk ị Europą! Ten kruta visi, - / Mes miegame, dunkso naktis!" ["Look at Europe! Everybody stirs there, / And 
we are sleeping in the middle of the night!"] (Maironis 1988: 414). Later, when the great empires fell in the final stages of World War I, Maironis revealed his vision of united European Parliament based on the principles of democracy:

Ir gal laikai - nebtolimi, / Kad bus Europoj renkami / Didžios respublikos atstovai / İ bendrą seimą nuo tautų, / Visų be skyriaus pašauktų, / Išnykus tarptautinei kovai.

[And perhaps the time will come, / When the representatives of great republic will be elected / To the united Seimas [Parliament] of nations, / Which all without exceptions will be called [to vote] / And the international wars will finish] (Maironis 1988: 252).

However, he did not support the ideas of social equality and individual liberties which were adopted in the left-wing pan-European political discourse.

Declaming such Eurocentric slogans Maironis did not feel himself alone. In 1904 the enthusiastic vision of the "United States of Europe" was introduced by a pious clergyman and Lithuanian patriot, Maironis's fellow Aleksandras Dambrauskas-Adomas Jakštas (1860-1938) who was overwhelmed by euphoria after the withdrawal of the ban on the printing of Lithuanian publications in Latin letters and relied on the authority of Western democracy. Catholic clergy maintained the dream of European intellectual integration, and St. Peter's throne was seen in the geopolitical vision of the Holy See as the centre of the space which was ruled by Catholic monarchs. Sceptical conservative clerics (e.g. Kazimieras Prapuolenis (1858-1933) who from 1912 was the unofficial representative of Lithuanians in Vatican) related tendencies of unification to the ideology of Russian pan-Slavism. They stated that "European alignment may be implemented not as unification of free citizens and nations, but as some kind of imperial expansion" (Staliūnas 2002: 113). Eurocentrism per se did not mean radical challenging of the governing conservative Russian regime and was not an act of direct opposition to the imperial propaganda.

In the poem Jaunoji Lietuva (Young Lithuania, 1907) by Maironis the mood of spring revival was related to the youthful activism of the newly selfproclaimed political nations:

Slovakai, lužičai ir net Pamarys, / Net suomių granitus aplankęs šiaurys / Už švintančią laisvę kovos. / Laimèkite, jaunos pakylančios šalys!

[Slovaks, Lausitz and even Pomore, / And even Finns with their granite, touched by north wind, / They all will struggle for the dawn of freedom. / So, let's seek victory, young and arising countries!] (Maironis 1988: 53). 
The poet was regarded as positivist who glorified the humanitarian achievements of newly liberated, dynamically emerging national states. The symbolic names of those statesmen and romantic-style historians were used as signal codes, calling for cultural resistance: "Karadzič, Šafarik, Dobrovski, Deake! / Vardai jūsų garsūs per amžius skambès" ["Karadzić, Šafárik, Dobrovský, Deák! / Your glorious names will sound forever"] (Maironis 1988: 54). The aforementioned Serbian, Czech, Slovakian, Hungarian historians and lawyers of relatively moderate, even monarchist views were part of the European cultural canon that was legalized in the Russian sphere of information, and Maironis could get to know them from short biographical notes in the contemporary editions of the Brockhaus encyclopedia. Maironis recalled the atmosphere of the "Spring of Nations" of the distant past, the first half of the $19^{\text {th }}$ century. Such anachronism was insignificant to the contemporaries of the poet who worked under the conditions of informational deficit: in Lithuania during the late Tsarist epoch achievements of the past and the present situation of European national movements were meditated as examples of equal value, as memorable lessons of history (Merkys 1987: 231). The analogy of Slavic "Spring of Nations" was urgent for Lithuanian nationalism during a very long period: as literary historian Mykolas Biržiška (1882-1862) recalled, the popular song by Maironis "Jau slavai sukilo..." ("The Slavs Had Already Arisen...", a fragment from Jaunoji Lietuva, which was put to music by the composer Juozas Naujalis (1869-1934) competed with Vincas Kudirka’s (1858-1899) “Tautiška giesmè" ("Song of the Nation", 1898) for the status of the official national anthem until 1919 (Biržiška 1953: 74).

\section{Social Criticism}

Maironis was among the first Lithuanian writers who criticized the theories of socialists and Marxists. The social question was discussed in his libretto Kame išganymas (Where Is Salvation, 1895). Zonis, the main character of this work of poetical drama, was represented as a creative genius alienated from reality and could be compared to Faust, Prometheus and lonely wanderers of Existentialism; the protagonist of the libretto was filled with idealism and wanted to embrace the whole mankind; on the other hand, he incited revolutionary anxieties and violence and at the end converted to Christianity inspired by a Franciscan monk. Zonis was acknowledged as the typical character of Western romanticism, expanding the repertoire of Lithuanian literary worldview. Full of idealistic intentions, he declared his intention to save mankind and grieved for the miseries of the proletariat. He instigated 
rebellious moods and witnessed the politically motivated acts of violence. The libretto could be interpreted as a poetical and philosophical reaction of pious Catholics to the rise of the Social-Democratic movement. It was also a reaction to the encyclical of the Pope Leo XIII (1810-1903) Rerum novarum (1891) which proposed the middle way between Liberalism and Socialism; amoral profit-seeking of liberal capitalism was denounced, but the Socialist doctrine was criticized more radically because it was breaking the foundations of society, giving prominence to economic interests only, and disclaiming the rights of personal ownership. Maironis interpreted the promises of socialists as manifestations of populism and justification of collective violence; he regarded slogans of freedom, equality and brotherhood as deceptive because all the revolutions turn into new forms of slavery.

During Soviet times it had been frequently stated that Maironis did not understand Socialism, mistook it for anarchism and that these misunderstandings determined the inner contradictions in his worldview and the clash of two cultures, popular democratic and bourgeois in his aesthetic curriculum (Zaborskaite 1987: 171). Today we can say that, on the contrary, Maironis was familiar with the main postulates of socialism; one can find the book of the famous German Social-Democratic thinker August Bebel (1840-1913) Die Frau und der Sozialismus (Woman and Socialism, 1879) in his private library. Maironis was highly interested in sociology and introduced it into the academic curriculum of the Kaunas spiritual seminary in 1909. He emphasized the value of labour and applied the socialist slogans in his lectures given to the future Catholic priests:

Darbas šiandien obalsis viso pasaulio ir milijonų lūpomis skamba: tasai tik turi teisę valgyti, kursai pats dirba, ne už kurị kiti dirba.

[Labour is a keyword of all the world today, and millions proclaim: only the working person has the right to eat, but the person for whom he is working, has not (from a lecture given in the Conference of Clerics, Kaunas, 2 September, 1919; Mačiulis-Maironis 2013: 11).

Priests have a duty of labour, and their specific mission obliges them to maintain solidarity with peasants and the industrial proletariat.

Meditating on the Pope's encyclical, Maironis modified its antisocialist dialectic, applying practical arguments from the agrarian context and therefore he related the right of ownership (of property) to the duty of labour because "the bread weeps when it is eaten by an idler" ("dyka duona valgoma verkia"; Maculevičia [Maironis] 1909: 287). Maironis recognized the simple wisdom of this proverb not only in socialist visions, but also in the teaching of the 
Apostles. The principles of justice were very important to him. He believed that conservative and moderate traditions may save people from man-made totalitarianism. Maironis had no illusions about the so-called socialist humanism, although he realized clearly that the $19^{\text {th }}$ century was the era of shameful social contrasts. In the later editions of the libretto Kame išganymas chaotic mass pathos of the 1905 revolution had been expressed openly. However, Maironis disassociated himself from Russian democratic polemists, keeping himself aloof from anti-monarchic instigations. Indeed, the poet welcomed the ideas of the cultural autonomy of nations that were declared by the self-proclaimed Great Seimas (Assembly) of Vilnius in December, 1905, but denounced the radical tendencies of the political movement. According to him, mankind could be saved only by the means of Christian devotion and loyalty to the conservative traditions. In his epic poem Tarp skausmu i garbę he depicted the atmosphere of terror which dominated during the French Revolution of 1789 as brutal and bestial, and only the spiritual virtues of "eternal Rome", the metaphorical cradle of Catholicism, could eventually save the modern world.

Maironis indirectly responded to the urgent questions of left-wing Russian social reformists Nikolay Chernyshevsky (1828-1889), Alexander Herzen (1812-1870) and Vladimir Lenin (1870-1924) - "Who is guilty [for all this]? What is to be done?". In the conflict of conservative and radical ideologies he recognized the dilemma of Christianity and secular atheism. In his libretto Maironis explored the possibilities of Christian sociology and fastened the progress of intellectual transformation and ideological differentiation of Lithuanian-speaking groups which corresponded with the strategies of "Christian actions" in Western Europe. It seemed that when Maironis emphasized his conservative worldview in Kame išganymas, he could anticipate the destructive nature of emerging radical trends of fascism and communism (Jonaitis [Šidlauskas] 1997: 170).

Maironis related atheism to the so-called scientism, the uncritical confidence in the progress of science and philosophy. In his poem Tarp skausmu i garbę Maironis equated academic experience, which was gained in the secular universities of Moscow or Warsaw, to some kind of dangerous poison. His discontent with the positivist tradition and the whole Tsarist system of education was determined by political conditions: in the late $19^{\text {th }}$ century in Lithuania the Catholic Church actually had lost control over the intelligentsia and could expect only tolerance, not obedience, nor strong support from it. In the legally printed Catholic newspapers, approved by Russian censorship, the secular positivists were regarded negatively, as "inner enemies" who caused as much danger as the Tsarist bureaucrats. Maironis considered Christian 
sociology to be a promising method for political conservatism as the opposition to any kind of radicalism.

Maironis himself harshly denounced not only socialism but all the philosophical trends which contradicted the Catholic orthodoxy, because for infidels neither God nor Christian ethics matter, and for them contradictory, morally indifferent or even openly immoral theories of Spencer, Condillac or Epicure allegedly could justify robberies, debaucheries and libertinism (Garnys [Maironis] 1895: 173). Economical and evolutionist theories of Karl Marx (1818-1883) and Charles Darwin (1809-1883) were associated with the "blasphemic" teachings of contemporary universities and allegedly caused the moral degradation and decadence of modern society. The conflict of clerics and laymen was one of the reasons why the consolidation of Lithuanian Christian Democrats was so complicated and why this party established its position in the political scene only when it had deliberately chosen socialistand even bolshevist-style rhetoric. For Maironis, the ideal state was a theocratic monarchy which could not be degraded by improper secular interpretations. The most dangerous of those trends seemed to be idealistic atheism, promoted by disillusioned intellectuals.

Maironis did not think that in Russian-ruled Lithuania social differences were as dramatic as they were in Western industrial urbanized societies. According to him, in the agrarian province there was no urgent division between capital and labour; and the lack of democratic institutions prevented the expansion of socialism. In the agrarian Lithuanian society after 1905 there was still no radical difference between forces of labour and capitalists, so the ideology of radical left movements and to prove to secular communities that Pope and highest clergymen took into account not only the claims of aristocracy and wealthy minority. After 1903, during the rule of the conservative Pope Pius $\mathrm{X}$ (1835-1914), it was a widely spread opinion that tendencies of modernism should be denounced because they instigated social unrest. Emphasizing social topics, clerics encouraged the forces of national movement and broadened the limits of public involvement: during this period the priests moved to the fields of mass agitation, established primary schools, trade unions and business cooperatives. Those lectures were in some sense the first organized "inventory" of Catholic social ideas and activities (Pruskus 1995: 103).

The main inspirer of the 1909 Kaunas public lectures on social topics was the future bishop of Vilnius and lecturer of sociology Jurgis Matulaitis (Jerzy Matulewicz in Polish, 1871-1927) whose views were close to the reformist spirit of Pope Leo XIII. Matulaitis was considered a potential mediator and conciliator between competing Lithuanian and Polish nationalist trends in the 
diocese of Vilnius. He was educated in the industrial cities of Kielce, Warsaw and Saint-Petersburg where he had direct contacts with representatives of the working class, and the problem of social inequality was known to him. The clerical authorities tried to represent themselves as arbiters between liberalism and socialism, however they were identified with the defenders of monarchy by their opponents. The credit of confidence of the Catholic Church was very high in Lithuania at the time, the first decade of the $20^{\text {th }}$ century. In his lecture Maironis reviewed views of the Holy See about the political movements of Christian Democracy. He blamed liberalism, moral indifference and the cult of profit for the extremeness of capitalism.

At the same time the question of property and ownership was decisive for Maironis. Property should be regarded as untouchable, and that was the primal principle for conservative thinkers. In his lecture Maironis equated ownership with identity (he used the definition savastis, 'identity', in the sense of nuosavybe, 'ownership'), mentioned the problem of existential minimum (existence was defined as gyvastis, a category of the same paradigm as savastis). Maironis supported temperance and self-restriction: an individual needs some property, but only a minimum of it for surviving and providing for his family. Christian ethics requires the defence of the institution of family and Maironis said that "family is the cradle of the future society" (Maculevičia [Maironis] 1909: 288). He revealed that socialism denied the necessity of family relations and foresaw new, artificial patterns of personal links. The greatest promise of socialism was equality which contradicted human nature because children are never born equal: people differ in their physical and mental development. The mechanic equalizing of mankind leads to the brutal forms of dictatorship and totalitarianism. By the way, democracy as such seemed not reliable to Maironis, too. He said that general elections are often won by populists who can promise everything and attract masses but seek only egoistic goals (Maculevičia [Maironis] 1909: 290).

Maironis's reflections on the situation of the working class were elementary, not motivated by personal encounters with this problem. The poet thought that problems of the proletariat were "imported" from Western industrial centres and that they were not related to the agrarian context of the Lithuanian society. Discussing those problems Maironis referred to the theories of authoritative Catholic sociologists (such as the archbishop of Mainz, Wilhelm Emmanuel von Ketteler, 1811-1877) on the demands for a ten-hour work day, decrease of the abuse of children in industrial plants, and decent payment which would enable the workers to subsist adequately. All the quarrels could be solved by the means of law, under legal conditions. People should respect the authority of the Catholic Church, restore centuries-old traditions, consider imperatives of 
charity. The rulers should unite communities, maintain Christian customs and protect the institute of family, and workers have their right to join associations, but they should also keep order and resist the radical political agitators.

Speaking about his opponents, Maironis was full of rage: "Socializmas aiškiai skelbia krikščionijai kovą, sutarties tarp jų būti negali ir vienam iš jų priguli ateitis" ["Socialism openly declares war to Christianity and there could be no treaty of peace between those forces; only one of them will be the winner in this battle"] (Maculevičia [Maironis] 1909: 300). There was no discussion possible; it was said that genuine leaders of the Catholic movement should dissociate themselves from politics. The alternative route of thinking, Christian Democracy, was represented as a non-political ideology, and the first political projects of this orientation from Belgium and Italy were denounced by the officials of the Holy See because such political organizations were regarded as a menace to the controlling institutions. Maironis did not rely on secular (even Christian-oriented) parties and demanded absolute obedience to the papal doctrine and encyclicals from loyal Catholics. The priests should be aware of the modern social theories, however the dogmas should also be carefully observed.

Matulaitis to a certain extent was a more liberal speaker than Maironis and socialism was not a reason for a crisis for him, but its logical result. Globalisation and global links gave rise to the extremes of liberalism: the telegraph, telephone and railways connected the most remote nations. In the vision of Matulaitis, Jesus Christ was the greatest social reformer who promoted ideas of freedom, equality and fraternity. Socialism, according to him, was the result of progress and fighting obscurantism. However he agreed with Maironis that the social question was related not only to the sphere of food or material goods but also to the categories of morality and faith (Matulevičius [Matulaitis] 1909a: 327350). Matulaitis revealed himself as a moralist, although his views on propriety rights were more flexible. He reminded people that societies of Communist type which were ruled according to the principles of community welfare and common ownership were not an innovation of the $19^{\text {th }}$ century Marxists but got inspiration from the ideas of the first Christian apostles and were practically implemented by the community of native Indian Americans which was established by Jesuits in Paraguay in the $17-18^{\text {th }}$ centuries (Matulevičius [Matulaitis] 1909b, 358). Matulaitis praised the economic and social politics of the United States of America where workers were not regarded as outsiders but were equally respected, appropriately integrated into the society and had opportunities to ensure their financial independence (Matulevičius [Matulaitis] 1909c: 381). 
ŽVIRGŽDAS

\title{
Conclusions
}

Criticizing socialism, scientism and atheism, the classical author of Lithuanian poetry and the central figure of the canon of national revival Jonas MačiulisMaironis represented himself as a persistent conservative, ethnolinguistic nationalist and antagonist of revolutionary upheavals. He speculated on the problems of social topics theoretically but was inclined to compromises, eulogizing classical, Roman-Christian laws of justice. This position was expressed in the programme of the Lithuanian Christian Democratic Union (1907), which was composed of professors of Saint-Petersburg Spiritual Academy for Roman Catholics, including Maironis himself. Maironis also contributed to the development of the right-wing political movement which took decisive action in 1918 when the projects of independent democratic republic came true (nevertheless he idealised the theocratic model of the state). In his lectures of 1909 Maironis demonstrated the intelligent, rational and practical ideology of the Catholic Church, and his fellow and colleague Jurgis Matulaitis proved himself to be a more sympathetic humanist and reformist, he was familiar with topics of poverty and the inequality of social classes. Social topics in Central Europe were regarded primarily as a reference to the national question. The younger generation of the Lithuanian clergy who supported the national movement and ideas of cultural autonomy often referred to the encyclical of Leo XIII Rerum novarum. According to moderate and conservative, clerical nationalist leaders of the emerging Lithuanian independence movement (Maironis, Prapuolenis, Jakštas, man of letters and editor of Christian-oriented newspaper Tévynés sargas Juozas TumasVaižgantas (1869-1933)), if love of homeland was given by God then it could not be in conflict with Christian faith.

\author{
Manfredas Žvirgždas \\ manfredasz@gmail.com \\ Lietuvių literatūros ir tautosakos institutas \\ Antakalnio g. 6 \\ LT-10308 Vilnius \\ LIETUVA / LITHUANIA
}


Ethnolinguistic Nationalism and Other Political Contexts of Maironis

\section{Bibliography}

Avižonis, K. 1957. Bendroji rusinimo politika - V. J. Bagdanavičius, P. Jonikas, J. Švaistas, eds. Kovos metai dèl savosios spaudos. Chicago: Lietuvių bendruomenès Čikagos apyg. leidinys, 29-65.

Bairašauskaitė, T.; Medišauskienė, Z.; Miknys, R. 2011. Lietuvos istorija, vol. 8, p. 1: Devynioliktas amžius: visuomenè ir valdžia. Vilnius: Baltos lankos.

Biržiška, M. 1953. Lietuviu tautos kelias, vol. 2. Los Angeles: Lietuvių dienos.

Garnys [Maironis]. 1895. Raszliaviszka peržvalga. - Žemaiczių ir Lietuvos Apžvałga, 22, 173-175.

Gellner, E. 2008. Nations and Nationalism. Ithaca, New York: Cornell University Press. Jonaitis [Šidlauskas], M. 1997. Minties ir veiksmo ịkalnè (Maironio Kame išganymas). Sociologija: Mintis ir veiksmas, 1(1), 169-175. https://doi.org/10.15388/SocMintVei. 1997.1.6614

Laukaitytė, R. 1995. Lietuvos katalikų dvasininkija per 1905-1906 metų revoliuciją. Lietuvos istorijos metraštis 1994 / The Year-book of Lithuanian History, 1994, 28 -51.

Laurinavičius, Č. 2013. Moderniųjų lietuvių raida nuo kalbinès link teritorinès bendruomenès. Pirma XX a. pusè. - Č. Laurinavičius, ed. Epochas jungiantis nacionalizmas: tautos (de)konstravimas tarpukario, sovietmečio ir posovietmečio Lietuvoje. Vilnius: Lietuvos istorijos instituto leidykla, 13-53.

Maculevičia, J. [Maironis]. 1909. Krikščioniškasis socialinės tvarkos mokslas pagal Leono XIII encyklikų. - Draugija, 31-32, 282-301.

Mačiulis-Maironis, J. 2013. Mokslas - tai didžiausia galybė: Neskelbtų tekstų fragmentai. A. Ruseckaitė, ed. Kaunas: Maironio lietuvių literatūros muziejus.

Maironis. 1987. Raštai, 1: Lyrika. I. Slavinskaitè, ed. Vilnius: Vaga.

Maironis. 1988. Raštai, 2: Poemos. I. Slavinskaitè, ed. Vilnius: Vaga.

Matulevičius [Matulaitis], J. 1909a. Trumpas išaiškinimas šių dienų socialinio klausimo. - Draugija, 31-32, 327-350.

Matulevičius [Matulaitis], J. 1909b. Bažnyčia ir nuosavybè. - Draugija, 31-32, 351-366.

Matulevičius [Matulaitis], J. 1909c. Miestų ir apskritai pramonijos darbininkų klausimas. - Draugija, 31-32, 367-384.

Merkys, V. 1987. Nacionalinio išsivadavimo judejjimas ir kitų tautų pažangioji visuomenè. - A. Eidintas, A. Gaižutis, V. Merkys, eds. Lietuvių nacionalinio išsivadavimo judejjimas (ligi 1904 metu). Vilnius: Mokslas, 216-241.

Pruskus, V. 1995. Katalikų socialinė mintis Lietuvoje (XIX a. antra pusè-XX a. pradžia). - Lietuvos katalikų mokslo akademijos Metraštis, 9, 23-224.

S. Z. [Maironis]. 1887a. Žodis prie Lietuviu mylincziu savo tēvynę. - Szviesa, 1, 3-7.

S. Z. [Maironis]. 1887b. Gromata Lietuvio. - Szviesa, 5, 203-205.

Staliūnas, D. 2002. Europos idejja lietuviškame XIX-XX a. sandūros diskurse. - D. Staliūnas, ed. Europos ideja Lietuvoje: istorija ir dabartis. Vilnius: Lietuvos istorijos instituto leidykla, 105-113.

Svarauskas, A. 2014. Krikščioniškoji demokratija nepriklausomoje Lietuvoje (1918-1940): politine galia ir jos ribos, Vilnius: Lietuvos istorijos instituto leidykla.

Zaborskaitè, V. 1987. Maironis. 2nd ed. Vilnius: Vaga. 